\title{
"Calcispheres" as a source of lime mud and peloids - evidence from the early Middle Devonian of the Prague Basin, the Czech Republic
}

\author{
STANISLAVA BERKYOVÁ \& AXEL MUNNECKE
}

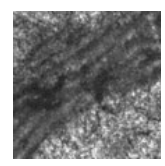

\begin{abstract}
Several types of peloids are present in the Lower and Middle Devonian limestones of the Prague Basin (uppermost part of the Třebotov Limestone of the Daleje-Třebotov Formation and Choteč Formation, uppermost Emsian-Eifelian) and are interpreted as being of calcispheral, echinoderm, and/or calcimicrobial origin. Possible mechanisms of peloid formation, the mode of life of calcispheres and their role in the accumulation of Paleozoic lime mud are discussed. Mass occurrences of peloids and calcispheres are characteristic features of the Choteč Formation (Eifelian, costatus-kockelianus conodont zones). It is concluded that specific environmental conditions, such as a higher nutrient load, existed during the sedimentation of this unit, probably in response to the Basal Choteč event. - Key words: calcispheres, peloids, micritization, lime mud, Prague Basin, Devonian.
\end{abstract}

BERKYOVÁ, S. \& MUNNECKE, A. 2010. "Calcispheres" as a source of lime mud and peloids - evidence from the early Middle Devonian of the Prague Basin, the Czech Republic. Bulletin of Geosciences 85(4), 585-602 (8 figures). Czech Geological Survey, Prague. ISSN 1214-1119. Manuscript received July 20, 2010; accepted in revised form October 27, 2010; published online December 13, 2010; issued December 20, 2010.

Stanislava Berkyová, Czech Geological Survey, P.O.B. 85, 11821 Prague 1, Czech Republic; berkyova.s@seznam.cz• Axel Munnecke, GeoZentrum Nordbayern, FG Paläoumwelt, Friedrich-Alexander Universität Erlangen-Nürnberg, Loewenichstraße 28, Erlangen, Germany; axel.munnecke@gzn.uni-erlangen.de

\begin{abstract}
Micritic matrix (i.e. lithified carbonate mud) and peloids are widespread constituents of carbonate rocks throughout the Phanerozoic, and various origins have been proposed for both of them. However, due to the scarcity of diagnostic features their origin is in many cases very difficult, if not impossible, to determine.
\end{abstract}

\section{The "micrite problem"}

The question of lime mud formation remains one of the key-issues in carbonate sedimentology, and still represents a rather puzzling topic. Whereas recent carbonate mud is composed mostly of aragonite and/or high-Mg-calcite, fossil micritic rocks are composed of low-Mg-calcite and/or dolomite. Three major problems arise especially when dealing with pre-Mesozoic micritic rocks. (1) At least since the Jurassic, the remains of calcareous planktic organisms (coccolithoporids, planktic foraminifera) constitute a significant part of many fine-grained carbonate rocks, but such organisms are unknown from the Palaeozoic (Bishop 1972, Di Nocera \& Scandone 1977). There is some evidence that some Palaeozoic calcareous microproblematica can be assigned to a planktic mode of live, but their volu- metric significance remains unknown (Munnecke \& Servais 2008). (2) The fine grain size of carbonate particles requires investigation using scanning electron microscopy, and (3) during lithification the original ultrastructure has usually been completely destroyed. Moshier (1989) summarized it as follows: "Since lithification involves dramatic reorganization of material and pore space, the problem is to reconstruct how, when, where, and why lime muds became the product we see today." Investigating micritic limestones therefore not only addresses the question of the primary composition of the unlithified sediment, but also the diagenetic processes resulting in the limestone lithification (Munnecke \& Samtleben 1996). In addition, late diagenetic alterations, e.g., during deep burial conditions or tectonic stress, can further alter the ultrastructure of the rocks.

During the past 130 years, various mechanisms for lime mud formation have been proposed (see, e.g., Flügel 2004). As early as 1879 Sorby mentioned several ways in which lime mud could be generated, including direct precipitation, biological and mechanical abrasion or disintegration of skeletal organisms into $\mu \mathrm{m}$-sized crystallites ("Sorby principle"). Among the plausible mechanisms suggested for micrite origin are physical-chemical precipitation 


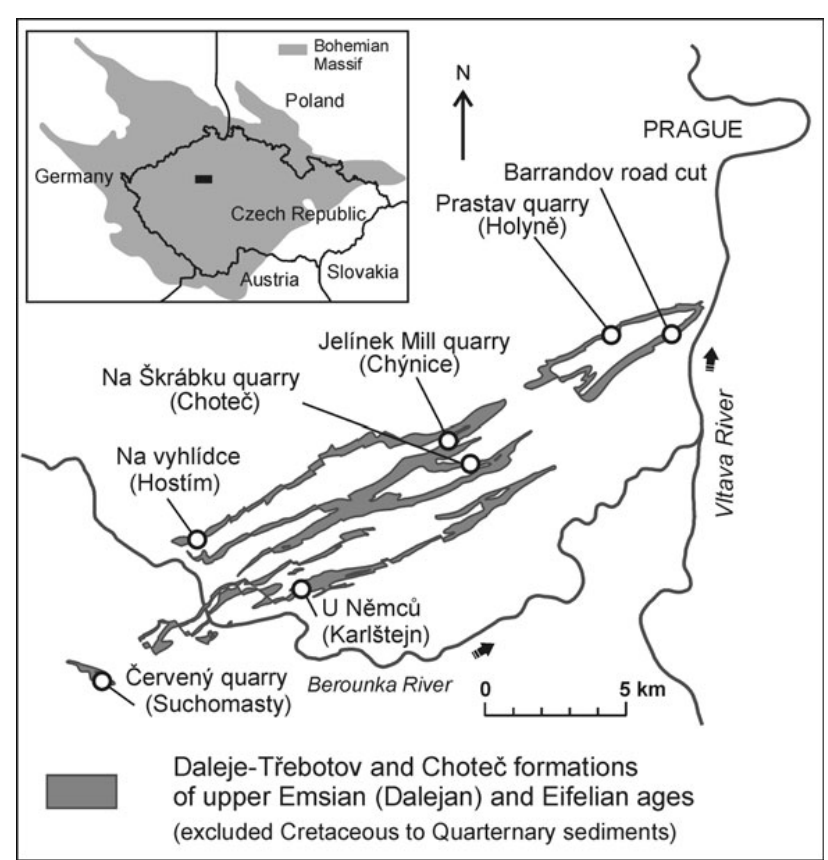

Figure 1. Schematic map showing location of the Prague Basin in the Czech Republic and distribution of Daleje-Třebotov and Choteč formations with positions of sections sampled for thin sections marked. Based on geological maps 1: 25000 published by Czech Geological Survey, slightly modified after Berkyová (2009).

of calcium carbonate (e.g. Cloud 1962, Milliman et al. 1993, Morse et al. 2003, Scoffin 1993, Serrano et al. 2009, Shinn et al. 1989), biologically induced and/or mediated precipitation (e.g. Buczynski \& Chafetz 1993, Chafetz 1986, Dittrich \& Obst 2004, McCallum \& Guhathakurta 1970, Monty 1995, Reid 1987, Robbins \& Blackwelder 1992, Riding 2000), mechanical and/or biological erosion of carbonate clasts (e.g. Pratt 2001, Stieglitz 1972), and disintegration of benthic calcareous algae (Coniglio \& James 1985, Lowenstam 1955, Lowenstam \& Epstein 1957, Neumann \& Land 1975, Stockmann et al. 1967). Formation of mud due to the carbonate grain diminution via micritization processes was discussed by Bathurst (1966), Klement \& Toomey (1967), Perkins \& Halsey (1971), Peterhänsel \& Pratt (2001), Swinchat (1965), Tudhope \& Risk (1985) and Young \& Nelson (1988). Lime mud formation due to the erosion and abrasion of micritized grains (micritization sensu Alexandersson 1972) was described by Reid et al. (1992). Many of the mechanisms of micrite formation described from modern environments probably also took place in ancient environments, e.g., microbially mediated precipitation (for review see, e.g., Monty 1995, Riding 2000), diminution of grains due to the activity of microborers (Klement \& Toomey 1967, Peterhänsel \& Pratt 2001), or disintegration of calcareous algae (Coniglio \& James 1985) or calcified cyanobacteria (Pratt 2001).
Due to the scarcity of diagenetically diagnostic features in micritic rocks considerably fewer papers deal with the transformation of soft sediments into lithified limestones (e.g. Bathurst 1970, Folk 1974, Lasemi \& Sandberg 1984, Steinen 1982). More recent investigations have shown that the process of transformation of aragonite-dominated carbonate muds (i.e. typical low-latitude, shallow-water carbonate mud) to solid rock occurs in a shallow marine burial environment in which small calcite crystals (microspar) are precipitated (Melim et al. 2002; Munnecke \& Samtleben 1996; Munnecke et al. 1997, 2008).

\section{Peloids}

Peloids are micron- to millimeter-sized, more or less structureless, subrounded micritic grains (Flügel 2004). The term includes (1) fecal pellets of various organisms eating lime mud, digesting the organic matter, and secreting the non-digested lime mud, (2) physically or biologically eroded biogenic components, (3) micritized intraclasts, (4) micritized ooids or bioclastic components, and (5) (bio-)chemical precipitates. Although it is often difficult to assign peloids viewed in thin sections to one (ore more) of these types, a correct interpretation can provide important information on the depositional setting, the palaeoenvironmental conditions, and diagenetic processes. The processes responsible for peloid formation could be variable. Bathurst (1966) called the process when the original grain fabric is altered and becomes cryptocrystalline in texture "micritization". The process of micritization can be the result of both mechanical and biochemical activity of boring microendoliths (mostly cyanobacteria, but also chlorophytes, fungi, red algae), and other organisms such as molluscs, sponges, polychaetes and foraminifers (e.g. Hutchings 2008, Santos \& Mayoral 2006). The empty borings eventually become filled with micrite. If this process is repeated several times, the carbonate grains are gradually and centripetally replaced by micrite, finally resulting in total micritization (Bathurst 1966, 1975). The term "micritization" has not always been used unambiguously. While Bathurst (1966) linked this process to algal microborings and subsequent filling of the microbores by micritic precipitates, Alexanderson (1972), on the other hand, suggested a broader definition without genetic implication, i.e. "alternation of preexisting fabric into micrite". A plethora of processes leading to grain diminution and thus to peloid formation has been described in the literature (for a summary of peloid types see Flügel 2004). It includes (a) peloid formation due to the boring activity of various organisms, most commonly algae, bacteria and fungi (Alexandersson 1972, Bathurst 1966, Friedman et al. 1971, Gunatilaka 1976, Hladil 2004, Hladil et al. 2004, Klement \& Toomey 1967, Kobluk \& Risk 1977, MacIntyre et al. 2000, Perkins 

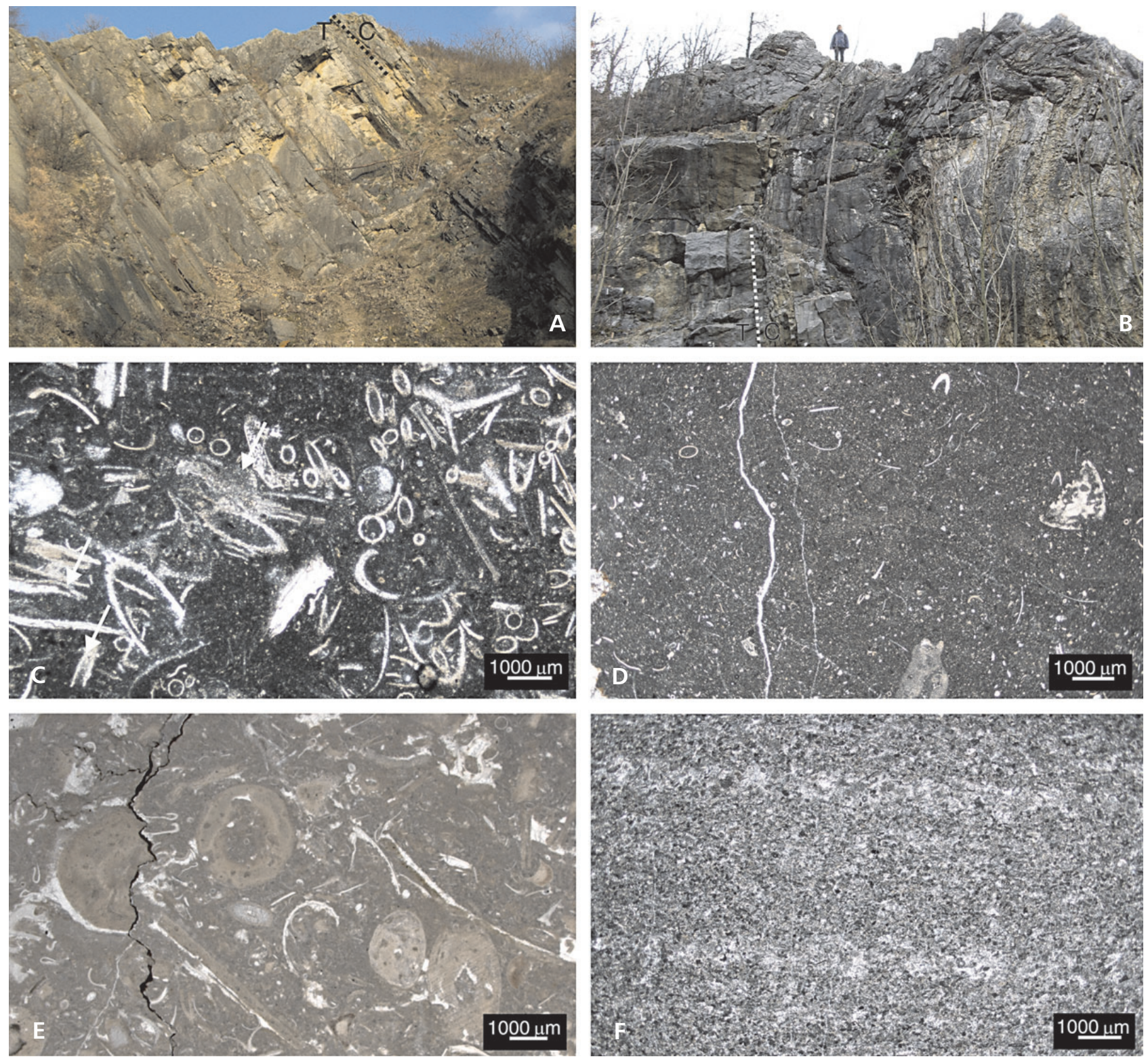

Figure 2. A - Prastav quarry, the regional reference section for the Lower-Middle Devonian boundary, with the Třebotov and Choteč Limestone boundary marked. • B - Na Škrábku quarry, the type locality for the Choteč Limestone with the Třebotov and Choteč Limestone boundary marked. - C - dacryoconarid wackestone to packstone (dacryoconarid tentaculites) from the Třebotov Limestone, Na Škábku quarry. • D - burrowed skeletal wackestone from the Choteč Limestone, Na Škábku quarry. • E - skeletal wacke-packstone from the Suchomasty Limestone with echinoderms, Červený quarry at Suchomasty. $\bullet \mathrm{F}$ - fine-grained peloidal grainstone, basal beds of the Choteč Limestone, Prastav quarry. Abbreviations used: T - Třebotov Limestone, C - Choteč Limestone.

\& Halsey 1971, Reid \& MacIntyre 2000, Tudhope \& Risk 1985), (b) peloid formation via processes of recrystallization (Neugebauer 1978, Purdy 1968, Reid \& MacIntyre 1998, Winland 1968), (c) algal and calcimicrobe breakdown and abrasion (Coniglio \& James 1985, Wolf 1965), and (d) mechanical abrasion of clasts weakened by previous algal borings (Samankassou et al. 2005, Young \& Nelson 1988). In addition to the skeletal origin of peloids, calcium carbonate precipitation, both biotic and abiotic (Bosak et al. 2004, Chafetz 1986, Hladil et al. 1996, Kaź- mierczak et al. 1996, Kendall \& Skipwith 1969, MacIntyre 1985, Reid 1987, Reitner 1993) as well as mud erosion and reworking (Fåhreaus et al. 1974) have also been suggested.

\section{"Calcispheres"}

Since Williamson (1880) erected the generic term Calcisphaera for specific calcareous microfossils as recorded in Carboniferous limestones from Wales, this term has been 
widely and rather loosely used. Calcispheres are usually denoted as hollow, spherical calcareous microfossils of various origins. Some calcispheres were interpreted e.g. as being representatives of volvocacean algae (Kaźmierczak 1976), reproductive cysts of dasycladacean green algae (Marszalek 1975, Rupp 1966), radiolarians (Antoshkina 2006), or post-mortem calcified acritarchs (Kaźmierczak $\&$ Kremer 2005). Many of the Mesozoic and Cenozoic calcispheres are now considered to be calcareous dinoflagellate cysts (Keupp 1981). However, the biological affinity especially of most Palaeozoic calcispheres remains less certain. The first fossil representatives of dinoflagellates are known from the Middle Triassic (Nicoll \& Foster 1994); however, there is a growing body of evidence which suggests that the stratigraphic age of this group is probably much older. Based on the presence of triaromatic dinosteroids, Moldovan et al. (1996) provided chemical evidence for the presence of dinoflagellate-like organisms in rocks of Precambrian and Devonian ages. Moreover, organisms possessing features characteristic of dinoflagellates were described by Butterfield \& Rainbird (1998) from Neoproterozoic sediments from Arctic Canada. Similarly, Servais et al. (2009) described Silurian calcareous microfossils resembling calcareous dinoflagellate cysts, and discussed their possible ancestral relationship to calcareous dinoflagellates. Versteegh et al. (2009) pointed out that the term "calcispheres" is inconsistently used in the literature, the morphological and taxonomical concepts are mostly ill-defined, and a formal definition is lacking. Therefore, these authors propose the new term "calcitarcha" for calcareous microfossils of unknown and probably varied biological affinities originally consisting of a central cavity enclosed by a wall of single or multiple layers.

Calcispheres are of limited value for palaeoecological reconstructions due to their unclear taxonomic position. However, a literature overview suggests that two environments were the main habitat of calcispheres, i.e. shallow water sheltered environments and an open marine realm. Calcispheres of various origin linked to a nutrient-rich, well sheltered, very shallow water such as lagoonal, backreef or even fresh water settings, were described by the following authors (with the interpretation of the calcispheres' affinity and age in parenthesis): Kaźmierczak (1975, 1976; Devonian, volvocacean algae), Kaźmierczak \& Kremer (2005; Devonian, post-mortem calcified acritarchs), Marszalek (1975; Holocene, dasycladacean algae), Reitlinger (1957; Devonian, probably algae - dasycladacean - remnants), Rich (1965; Devonian, unknown origin), Rupp (1966; Cretaceous and recent, reproductive cysts of dasycladacean algae), Stanton (1967; Devonian, unknown origin), and Vecsei \& Duringer (1998; Triassic, unknown origin). Calcispheres from open marine environments were described by Adams et al. (1967; Cretaceous, calcareous dinoflagellate algae), Bein \& Reiss (1976; Cretaceous, calcareous dinoflagellate algae), Bishop (1972; Cretaceous, planktonic organisms of unknown origin), Konishi (1958; Devonian, various groups of organisms), Munnecke \& Servais (2008; Silurian, probably planktonic organisms of unknown origin), Servais et al. (2009; Silurian, possible ancestors of calcareous dinoflagellates), and Wiese et al. (2004; Cretaceous, calcareous dinoflagellate algae).

As already pointed out by Flügel (2004) and indicated by the above listed authors, calcispheres occurring in an open marine realm mostly represent calcareous dinoflagellates, or organisms related to them, and are most frequently reported from Mesozoic rocks, whereas pre-Mesozoic calcispheres seem to be restricted to shallow-water environments.

\section{Aim of the study}

The accumulation of calcareous plankton plays a major role in carbonate sedimentation in modern depositional systems, especially in pelagic areas. The first calcareous plankton related to modern calcareous plankton, however, is reported from the late Triassic (Bellanca et al. 1995, Di Nocera \& Scandone 1975), and becomes quantitatively more important from the Jurassic onwards (Bown et al. 2004, Gartner 1977, Mutterlose et al. 2005, Ridgwell 2005). The question arises as to what was the main source of Palaeozoic pelagic lime mud, considering the lack of

Figure 3. A-D, F-I - well preserved radiosphaerid calcispheres with micritic rim recognizable both in the outer and inner walls. $\bullet$ A, C, H - Prastav quarry, $0.09 \mathrm{~m}$ above the base of the Choteč Limestone. $\bullet \mathrm{B}$ - Prastav quarry, $0.9 \mathrm{~m}$ above the base of the Choteč Limestone. $\bullet \mathrm{D}-\mathrm{Prastav}$ quarry, $1.7 \mathrm{~m}$ above the base of the Choteč Limestone. $\bullet$ F - Jelínek mill quarry, initial few centimeters of the Choteč Limestone. $\bullet$ G - Na Škrábku quarry, uppermost Třebotov Limestone, $0.08 \mathrm{~m}$ below the base of the Choteč Limestone. $\bullet$ I - Na Škrábku quarry, initial few centimeters of the Choteč Limestone. $\bullet$ E - probably micritized radiosphaerid calcisphere with undistinguishable outer and inner walls due to the advanced stage of micritization, Prastav quarry, $0.09 \mathrm{~m}$ above the base of the Choteč Limestone. $\bullet \mathrm{J}-\mathrm{L}$ - well preserved non-radiosphaerid calcispheres with micritic rim recognizable both in the outer and inner walls. $\bullet \mathrm{J}-$ Barrandov road-cut section, $0.5 \mathrm{~m}$ above the base of the Choteč Limestone. $\bullet \mathrm{K}, \mathrm{L}-\mathrm{Na}$ Škrábku quarry, Třebotov Limestone, $1.5 \mathrm{~m}$ below the base of the Choteč Limestone. - M-R - poorly preserved calcispheres with fuzzy boundaries suggestive of an advanced stage of micritization. - M - Barrandov road-cut section, $0.5 \mathrm{~m}$ above the base of the Choteč Limestone. $\bullet \mathrm{N}$ - Prastav quarry, Třebotov Limestone, $5 \mathrm{~m}$ below the base of the Choteč Limestone. $\bullet \mathrm{O}, \mathrm{P}-\mathrm{Na}$ Škrábku quarry, uppermost Třebotov Limestone, $0.08 \mathrm{~m}$ below the base of the Choteč Limestone. $\bullet \mathrm{Q}-\mathrm{Na}$ Škrábku quarry, $1 \mathrm{~m}$ above the base of the Choteč Limestone. $\bullet \mathrm{R}-\mathrm{Na}$ Škrábku quarry, $7 \mathrm{~m}$ above the base of the Choteč Limestone. $\bullet$ S-T - peloids probably of calcisphere origin, Prastav quarry, $0.9 \mathrm{~m}$ above the base of the Choteč Limestone. Scale bars represent $100 \mu \mathrm{m}$. 

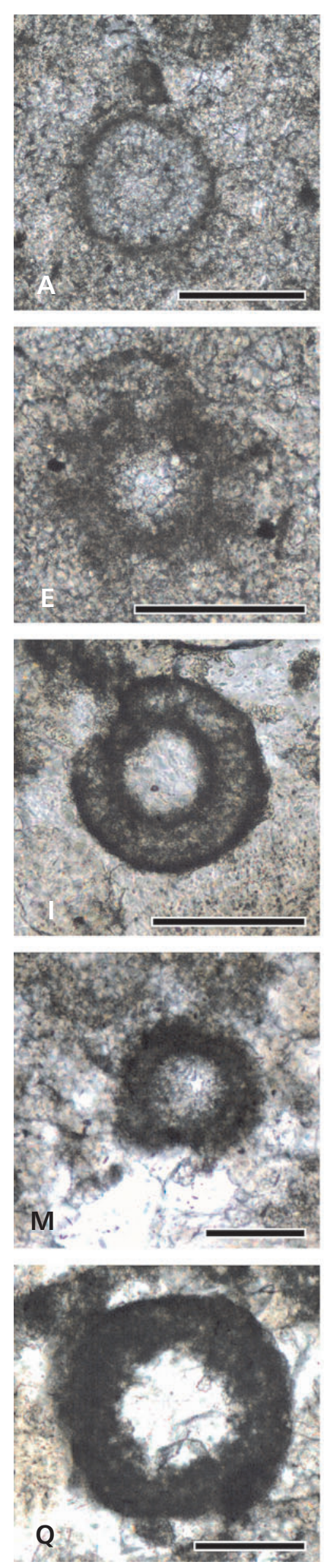
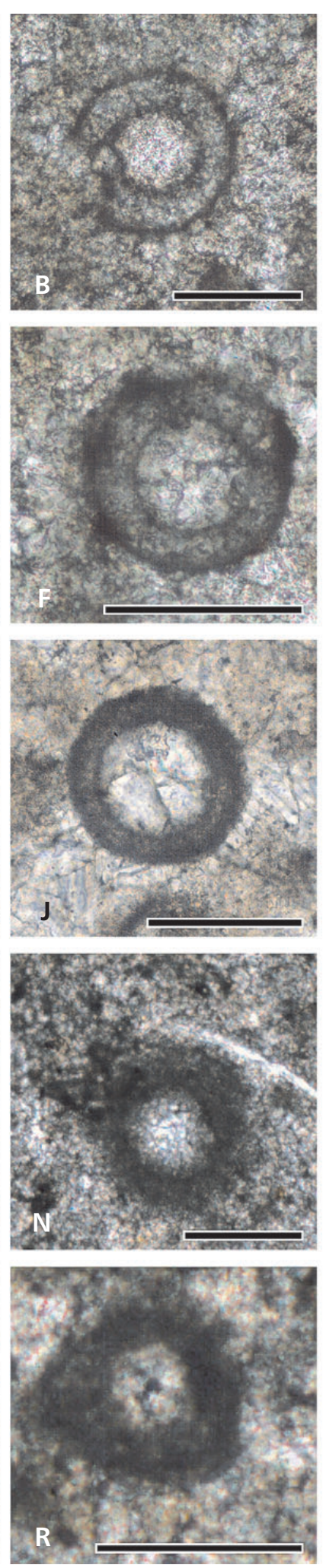
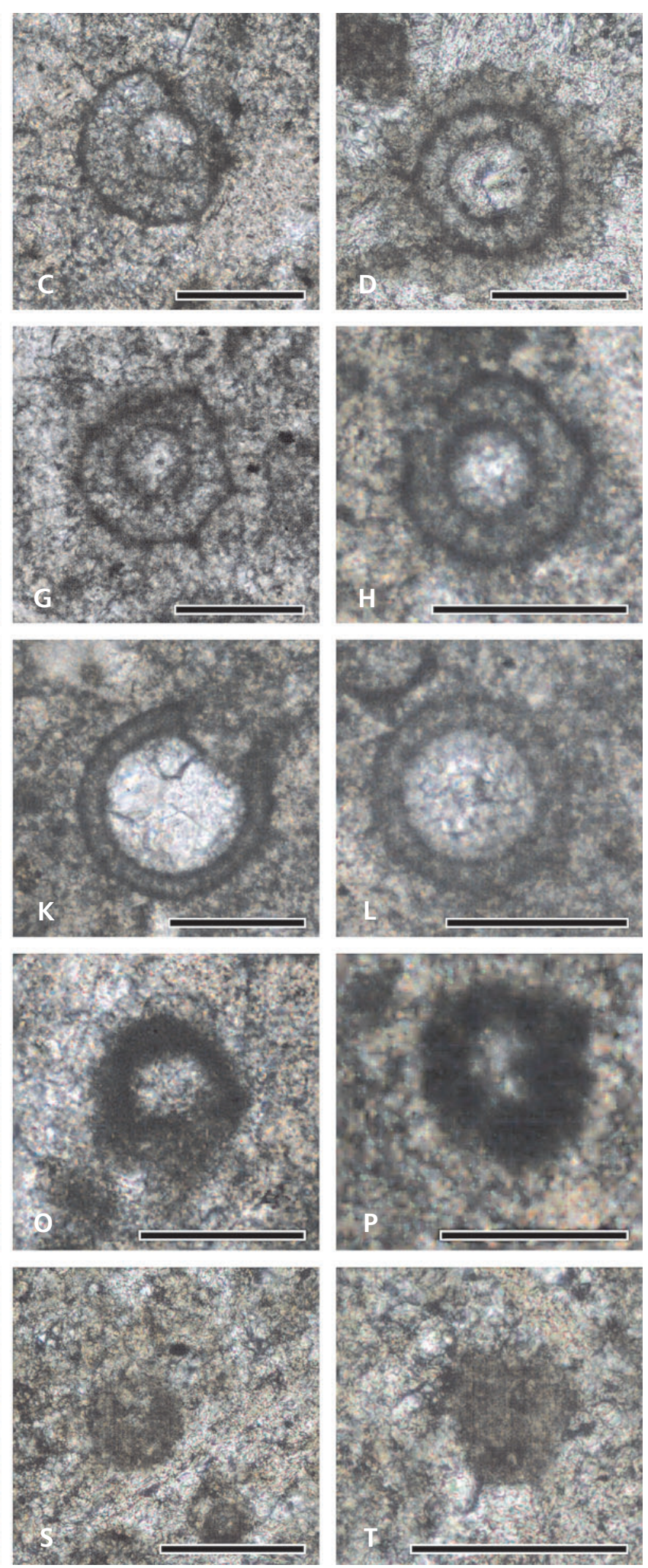
calcareous plankton at that time? Munnecke \& Servais (2008) and Munnecke et al. (1999) described calcareous microfossils, so-called calcispheres and nannospheres, from the Silurian strata of Gotland and regarded them as probably planktic organisms. However, the occurrence of pre-Mesozoic calcareous plankton are often doubted (Bown et al. 2004, Muttelose et al. 2005). In this paper we report large accumulations of Devonian (late Emsian-early Eifelian) calcispheres and several types of peloids from the Prague Basin (the Czech Republic). Calcispheres together with other grains display various degrees of degradation, and we discuss their contribution to the production of lime mud.

\section{Geological setting}

The study area is located in the Teplá-Barrandian unit (Fig. 1) in the central part of the Bohemian Massif, which is regarded as a Gondwana-derived crustal block comprised of a Neoproterozoic (Cadomian) basement unconformably overlain by Lower Palaeozoic strata (see e.g., Chlupáč et al. 1998; Franke 1989, 2000; Kachlík 1999). The infill of the Prague Basin (Havlíček 1981) is comprised of volcanosedimentary successions of Lower Ordovician (Tremadoc) to Middle Devonian (Givetian) age (summary in Chlupáč et al. 1998). Since the early Ludlow (Silurian) and up to the Givetian, carbonate deposition prevailed due to the drift of this part of peri-Gondwana into low palaeolatitudes (e.g. von Raumer \& Stampfli 2008, and references herein).

Devonian rocks, especially those of Pragian age (Lower Devonian) deposited in the Prague Basin, display highly diverse depositional environments, from basinal to reefal facies. During the late Early-Middle Devonian (late Emsian-Eifelian), when facies pattern show less diversification, shallow-marine skeletal-rich carbonates predominated towards the SW and NW parts of the basin, with deeper water offshore carbonates dominating towards the SE and NE. Sedimentation in the Prague Basin was terminated during the Givetian by the siliciclastic flyshoid sequences of the Srbsko Formation (see e.g. Budil 1995), the deposition of which was linked to the closure of the basin as result of incipient Variscan deformation (Petránek 1950, Kukal \& Jäger 1988).

We studied the micritized calcispheres and peloids of various origins occuring within the Lower-Middle Devonian deposits of the Prague Basin, i.e. the Třebotov
Limestone (Daleje-Třebotov Formation, Lower-Middle Devonian, upper Emsian-Eifelian) and the Choteč and Acanthopyge limestones (Choteč Formation, Middle Devonian, Eifelian) (Figs 1,2). A summary of the stratigraphy, paleontology and facies distribution of these units was given by Chlupáč et al. (1998, and references herein). The Třebotov Limestone, representing the offshore facies, consists of well-bedded, nodular, reddish and light-gray micritic limestones with diverse planktic, nektic, and benthic fauna (Fig. 2C) (see Chlupáč et al. 1979 and references herein). Based on the faunal assemblages, Chlupáč (1977, 1983) assigned these deposits to a muddy, relatively deep and calm environment. A different environment was established for the Koněprusy area, where the equivalent of the Třebotov Limestone, the Suchomasty Limestone, was deposited in a shallow-water marine setting. The depositional environment of the latter limestone was interpreted by Havlíček \& Kukal (1990) as "shallow water, temporarily agitated, temporarily quite", distant from any high-energy platform margin, with abundant benthic fauna, being aspecially rich in trilobites, brachiopods and crinoids (Fig. 2E). A basin-wide change in the sedimentation pattern occurred in the early Eifelian (uppermost partitus-basal costatus zones) at the onset of sedimentation of the Choteč Formation (Choteč and Acanthopyge limestones). This unit reflects in its development and fossil content perturbations and non-steady-state conditions linked to the Basal Choteč event. This has been regarded as a minor but important eustatic transgressive event in the Middle Devonian, early Eifelian, uppermost partitus-basal costatus zones (e.g. Chlupáč \& Kukal 1986, 1988 and references herein; House 2002; Elrick et al. 2009; Walliser 1985, 1996). The Choteč Limestone is comprised of calciturbidites (Plusquellec \& Hladil 2001, see also Suchý 1991 for different interpretation) consisting of dark gray, graded peloidal grainstones with crinoid ossicles (Fig. 2F) and crinoidal grainstones with peloids which alternate with the background sediments of dark gray, burrowed to laminated lime mudstones and burrowed/bioturbated light-gray skeletal wackestones (Fig. 2D). Chert is common, especially in the eastern, southeastern and central parts of the basin. The depositional environment of the Koněprusy area, where the Acathopyge Limestone was deposited, was interpreted by Kukal in Havlíček \& Kukal (1990) as extremely shallow water, with peloid-rich sediments, similar

Figure 4. A-D - peloids reflecting a calcisphere origin, Prastav quarry, $1.7 \mathrm{~m}$ above the base of the Choteč Limestone. $\bullet$ E - peloidal packstone with arrows pointing to the two calcispheres showing different stages of grain alteration, Na Škrábku quarry, uppermost Třebotov Limestone, 0.08 m below the base of the Choteč Limestone. $\bullet \mathrm{F}$ - probably micritized radiosphaerid calcisphere with undistinguishable outer and inner wall due to the advanced stage of micritization, Na Škrábku quarry, $0.2 \mathrm{~m}$ above the base of the Choteč Limestone. $\bullet \mathrm{G}$ - fine-grained peloidal grainstone with a peloid probably of calcisphere origin in the center of the picture, Na Škrábku quarry, $0.2 \mathrm{~m}$ above the base of the Choteč Limestone. $\bullet \mathrm{H}-\mathrm{enlarged}$ view of peloid shown in Fig. 4G. $\bullet$ I, J - peloidal packstone-grainstone with calcispheres showing different stages of grain alteration, Prastav quarry, $0.15 \mathrm{~m}$ above the base of the Choteč Limestone. Scale bars represent $100 \mu \mathrm{m}$. 

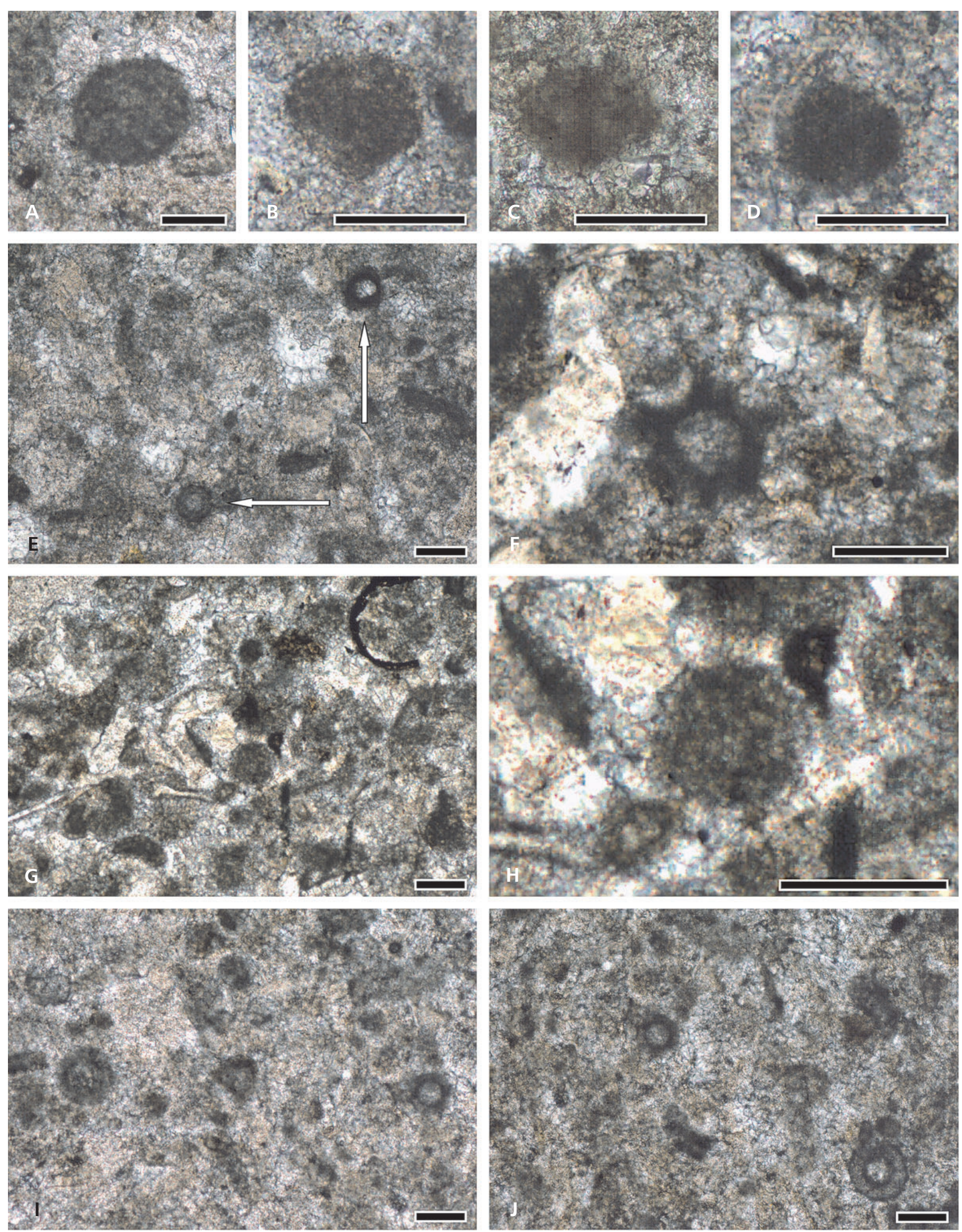
to recent deposits on the Bahama Bank (so-called bahamites). Peloids within the Choteč Formation were also mentioned by Petránek (1946), who described the structure of the Choteč Limestone as "structure grumeleuse".

\section{Material and methods}

The localities sampled for microfacies analysis in the Prague Basin (Fig. 1) are: Barrandov road-cut, Prastav quarry, Jelínek Mill quarry, Na Škrábku quarry, Hostím section, U Němců section and Červený quarry. Sampling was carried out bed by bed, with particular regard to facies changes observed in the field. More than 240 thin sections (cut perpendicular to the bedding plane) of the format $3 \times 4,5 \times 5$ and $5 \times 10 \mathrm{~cm}$ were studied. Dunham's (1962) carbonate classification was followed. The number of components was determined using Flügel's (2004) estimation charts. Digital photographs of thin sections were taken with a Nikon Eclipse E600 and Nikon Eclipse 80I microscopes and Pixelink PL-A642 and Nikon DS-Fi1 cameras.

\section{Results}

\section{Types of calcispheres observed}

Mass accumulations of calcispheres were recorded in the allochthonous grainstones of the Choteč Formation (costatus-kockelianus zones), in the peloidal packstones of the uppermost Třebotov Limestone (upper partitus-basal costatus Zone), and occasionally in the autochthonous micritic Třebotov and Choteč limestones. Two different morphotypes of calcispheres were recorded in this study. The first morphotype is represented by calcispheres bearing external spines (radiosphaerid calcispheres), with a diameter ranging from $80-120 \mu \mathrm{m}$ and wall thickness ranging from 20 to $30 \mu \mathrm{m}$ (Figs $3 \mathrm{~A}-\mathrm{I}, 4 \mathrm{~F}$ ). The second morphotype is represented by smooth calcispheres with size ranging from 120 to $180 \mu \mathrm{m}$ and wall thickness ranging from 20 to $25 \mu \mathrm{m}$ (Fig. 3J-L). Differentiation between these two calcisphere morphotypes was only possible for specimens which were not completely micritized. The outer and inner surface of the walls in both types of calcisphere show a dark micritic rim. Such a rim was recorded in all of the calcispheres observed. The calcispheres show various stages of preservation, from well-preserved specimens with a thin micritic envelope (Fig. 3A-D, F-L) to specimens with somewhat diffuse outlines (Figs 3E, M-R, 4E, F), and finally to specimens with a fuzzy appearance, where the inner, primarily hollow part of the calcisphere was nearly nonexistant (Figs 3S-T, 4A-D, G-H, 5A-E, G). Micritic envelopes were observed around calcispheres and echinoderm remains. These form the vast majority of grainstone components. Other bioclasts occur only in limited numbers (mainly preserved fragments of ostracods, brachiopods and trilobites, forming $\leq 10 \%$ of the clasts present), but their micritization was only rarely observed.

\section{Peloids}

The presence of peloids was noted in some sections of the uppermost Třebotov Limestone (peloidal packstones) and especially in the allochthonous beds (calciturbidites) of the Choteč Formation (peloidal grainstones with crinoids and crinoidal grainstones with peloids). Several types of peloids have been observed. The first group is represented by small (80-180 $\mu \mathrm{m})$, rounded, fuzzy "clouds" of micrite (Figs 3T, 4B-D, G-H, 5A-E, G) and rounded peloids (Figs 3S, 4A). This type of peloid forms mass accumulations in the grainstones of the Choteč Formation together with micritized calcispheres, crinoidal ossicles, and other types of peloids. Another type of peloid is present particularly in the proximal calciturbidites within the Choteč Formation. These peloids, which lack any visible internal structure, have more distinct grain boundaries and are polygonal in shape (most commonly with a rounded polygonal shape) (Fig. 6F). They occur together with abundant crinoidal ossicles showing different stages of micritization, from well-preserved ossicles to heavily micritized grains in which, however, the original crinoidal nature is still visible (Fig. 6C, E, G-H). The third type is represented by calcimicrobial peloids of various shapes in which the filaments of Girvanella are still recognizable (Fig. 6A, C). It should be noted that the latter type of peloids are rare; peloids without any inner structure (see above) prevail overall. In summary, three basic types of peloids were observed, in particular in the Choteč Formation.

Even though the joint occurrences of all the above mentioned peloid types were recorded and are common, a link appears between certain types of peloid and particular lithotypes. The first type of peloids (small, rounded clouds of micrite) occurs in the uppermost peloidal packstone of

Figure 5. A-E - peloids probably of calcisphere origin. • A, B - Prastav quarry, $0.15 \mathrm{~m}$ above the base of the Choteč Limestone. $\bullet$ C - Barrandov road-cut section, $0.5 \mathrm{~m}$ above the base of the Choteč Limestone. $\bullet \mathrm{D}-\mathrm{Na}$ Škrábku quarry, uppermost Třebotov Limestone, $0.08 \mathrm{~m}$ below the base of the Choteč Limestone. $\bullet$ E - Jelínek mill quarry, 2.4 m above the base of the Choteč Limestone. $\bullet \mathrm{F}-\mathrm{H}$ - abraded clusters of Girvanella filaments. $\bullet \mathrm{F}-$ Jelínek mill quarry, first few centimeters of the Choteč Limestone. $\bullet \mathrm{G}$ - Jelínek mill quarry, $2.4 \mathrm{~m}$ above the base of the Choteč Limestone. • H - Na Škrábku quarry, first few centimeters of the Choteč Limestone. Scale bars represent $100 \mu \mathrm{m}$. 

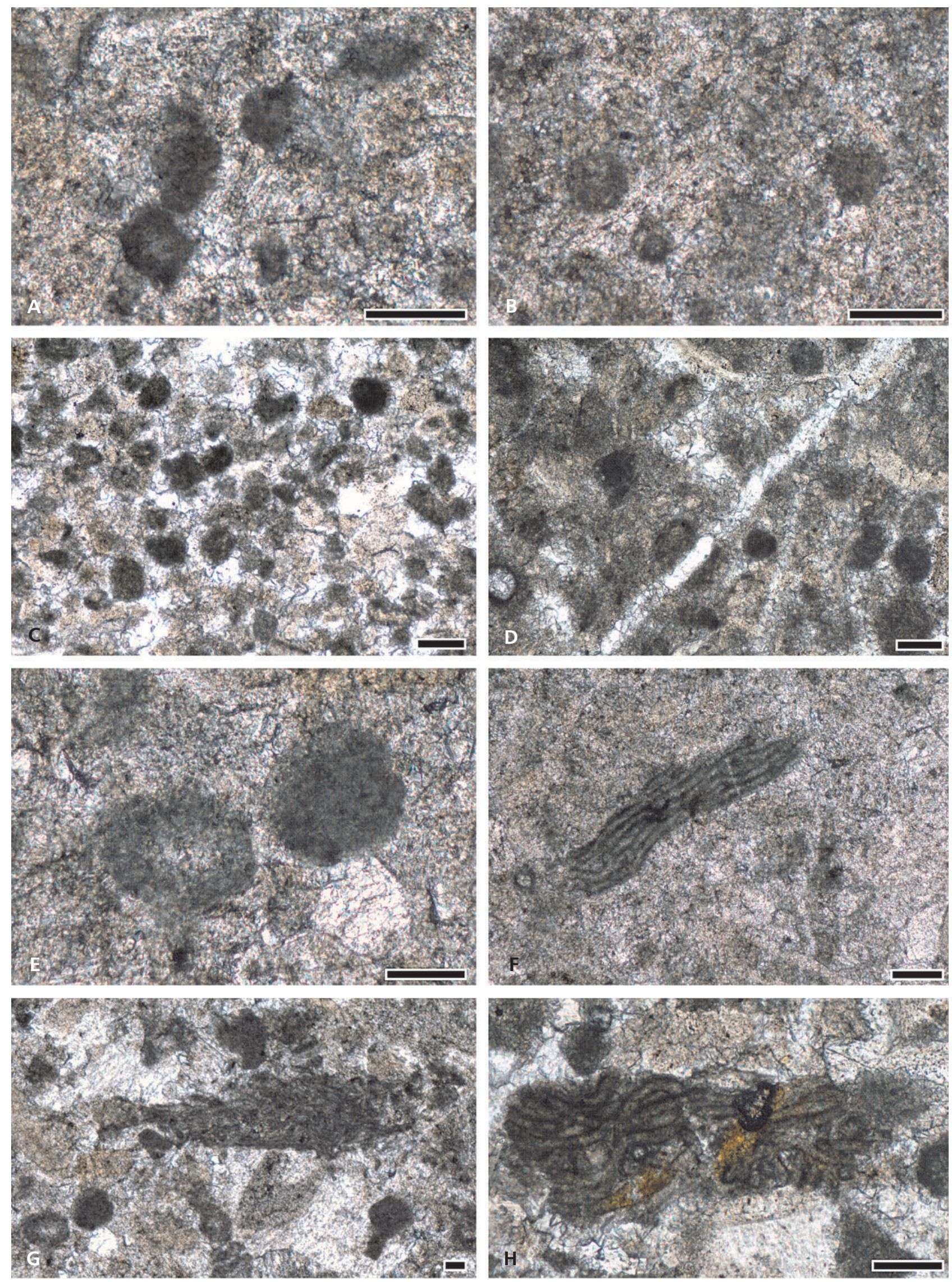
the Třebotov Limestone together with micritized calcispheres, forming up to $20 \%$ of the rock components, and in the distal, fine-grained peloidal grainstones of the Choteč Formation (together with micritized calcispheres forming up to $35-40 \%$ of the rock components). The other peloidal types (peloids of rounded polygonal shape) mainly occur in the more proximal crinoidal grainstones of the Choteč Formation (forming around $30-40 \%$ of the rock components). It is worth mentioning that an increase in peloid abundance (rounded clouds of micrite and micritized calcispheres) was recorded from the early partitus Zone (early Eifelian, Middle Devonian) in all of the sections studied in the Třebotov Limestone. An average number of 5 to 10 micritized calcispheres and/or rounded peloids per thin section were observed. Even though these abundances are incomparable to the mass accumulations of calcispheres and rounded peloids recorded in the Choteč Formation (costatus Zone), it does represent a noticeable change (approximately double-triple the original amount) in comparison to the underlying beds of the Třebotov Limestone (serotinus and patulus zones).

\section{Discussion}

\section{The origin and mode of life of the Devonian calcispheres}

The biological affinity of calcispheres is unknown and still represents a matter of debate. Calcispheres undoubtedly represent a polyphyletic group of calcareous microfossils (Versteegh et al. 2009). Obviously, a plethora of organisms (both animals and plants) could produce fossilized structures which are fossilized structures, which fulfill the definition of the calcisphere group (see Versteegh et al. 2009). When comparing, e.g., calcispheres in Fig. 3J-L with recent reproductive cysts of dasycladacean algae as illustrated by Marszalek (1975) and Scholle \& Ulmer-Scholle (2003, p. 62) some similarities can be seen. In the same way some similarities to calcareous dinoflagellate cysts exist. The resolution of calcisphere affinity is beyond the scope of this paper as no detailed ultrastructural study could be carried out on the samples due to the poor preservation of their structure. As already mentioned, only calcispheres with micritic rims were observed. Micritic rims were observed especially in calcispheres and echinodermal remains but only rarely at other bioclasts which formed only a limited component of the grainstones. It is important to note that well-preserved echinoderms and other skeletal remains without micritic coatings were also recorded together with micritized remains. The calcispheres studied, on the other hand, always exhibit a micritic coating. It seems therefore that such a rim represents a characteristic feature of calcispheres recorded herein, and is probably pertinent to the original structural composition of these calcispheres. Therefore we suggest that calcispheres, whether representing individual biological entities or reproductive organs, possessed some kind of mucilaginous envelope covering their body. The assumption that calcisphere bodies were embedded in a mucilaginous cover would shed more light on another important question, i.e. what was the mode of the life of calcispheres? As shown e.g. by Reynolds (2006) the presence of mucilage surrounding the body could represent an adaptation for a planktic mode of life (density reduction, protection). However, as no direct proof for the presence of a mucilaginous cover is available, the question of the calcisphere's mode of life remains undetermined.

\section{Peloids origin}

Three types of peloid were recognized: Type 1: The first type is represented by small, rounded clouds of micrite (Figs 3S-T, 4A-D, G-H, 6A-D, E). These peloids form mass accumulations together with calcispheres (and other types of peloids). Based on the comparable size and shape of calcispheres and peloids and the co-occurrence of calcispheres and these peloids we concluded that these peloids are, at least in part, of calcisphere origin.

Type 2: The second type of peloids recorded are those with distinct grain boundaries and rounded polygonal shape (Fig. 6D, F). Considering their shape and the fact that crinoid ossicles are the dominant component of the grainstones, a crinoid origin for these peloids is highly probable. Moreover, as already mentioned, various stages of crinoidal ossicle degradation were noted, i.e. unaltered ossicles, ossicles possessing a micritic envelope and micritized ossicles, but still recognizable as echinoderm remains (Figs 6B, C, E-H, 7). However, a different origin for

Figure 6. A - calcimicrobial peloid, origin probably an abraded cluster of Girvanella filaments. $\bullet$ B-C, E, G-H - crinoidal ossicles showing different stages of grain alteration, note the centripetal mode of alteration which is typical for micritization sensu Bathurst (1966). B, C - U Němců section, $3.6 \mathrm{~m}$ above the base of the Choteč Formation (note also calcimicrob Girvanella peloid in Fig. 6C). $\bullet$ D - crinoidal grainstone with peloids (peloids of the type II prevail), $1.7 \mathrm{~m}$ above the base of the Choteč Limestone, Prastav quarry, scale bar is $1000 \mu \mathrm{m}$. $\bullet$ E, $\mathrm{H}-\mathrm{Na}$ Skrábku quarry, first few centimeters of the Choteč Limestone. $\bullet \mathrm{G}$ - Jelínek mill quarry, $2.4 \mathrm{~m}$ above the base of the Choteč Limestone. $\bullet \mathrm{F}$ - peloids without internal structure, showing more distinct grain boundaries and polygonal shape, probably of crinoidal origin, $2.4 \mathrm{~m}$ above the base of the Choteč Limestone. Scale bars represent $100 \mu \mathrm{m}$ if not stated otherwise. 

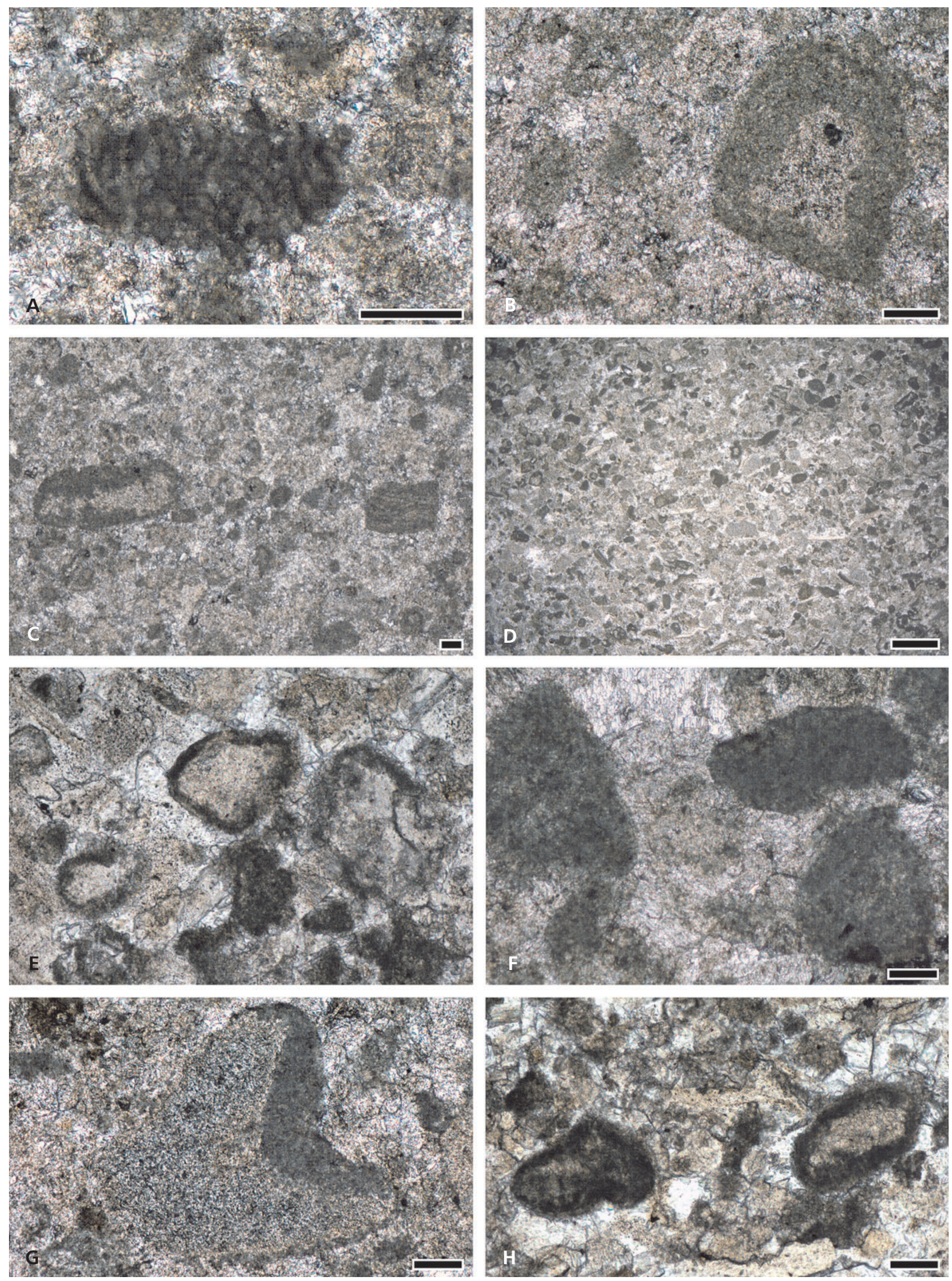

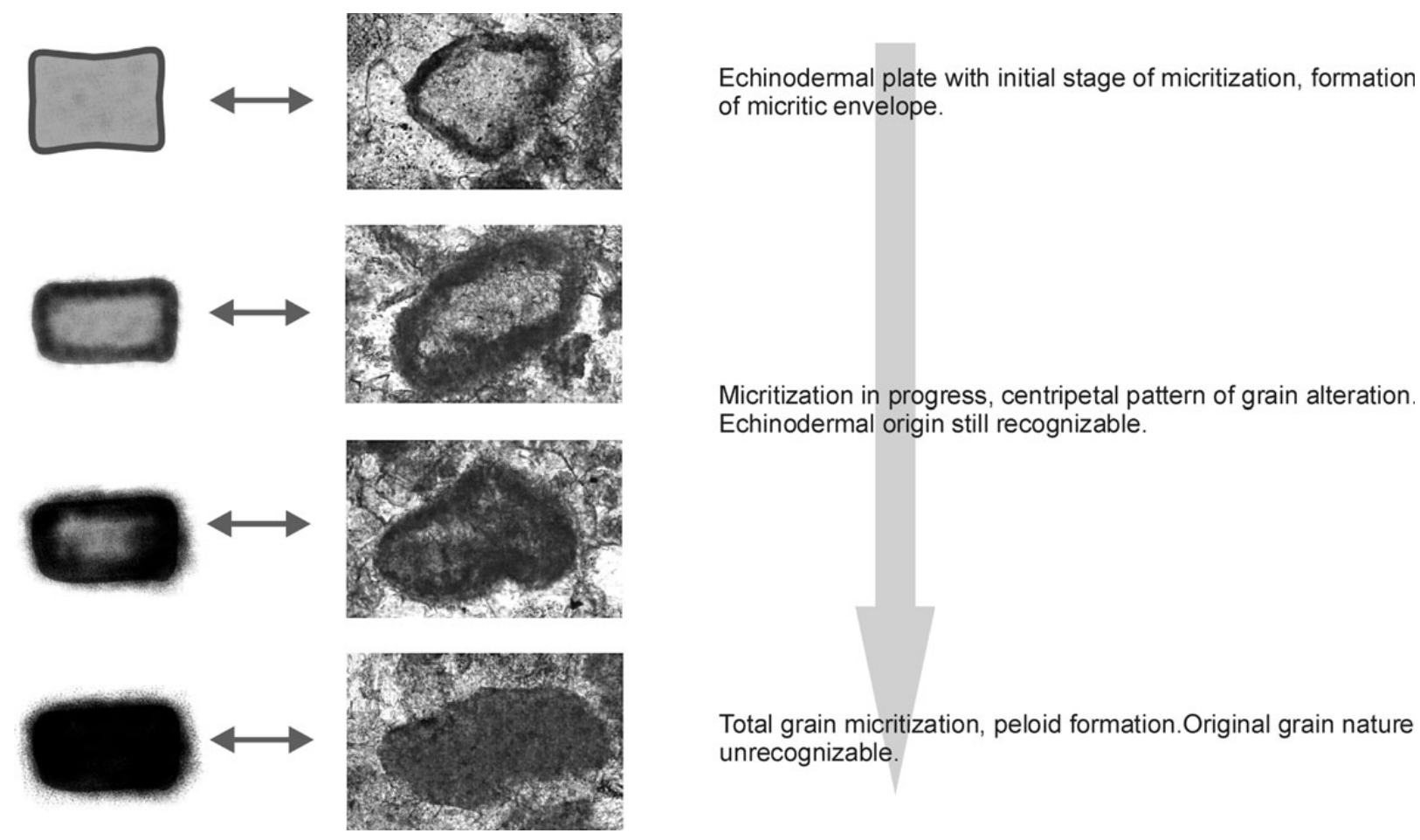

Figure 7. Schematic sketch showing centripetal micritization of crinoidal ossicles.

some of these peloids, such as micritized bioclasts, is also possible and cannot as yet be ruled out.

Type 3: The third type of peloid is made up of Girvanella clusters (Fig. 6C on the right). It is plausible that some of the second type of peloids might also have been from the same origin, but with the alteration of grains being more advanced and therefore without any recognizable inner structure.

To sum up, the peloids reported here can be divided into two groups: those of unknown origin and peloids whose origins can be identified. The peloids with speculative origins (those with rounded rectangle shape) commonly occur in the crinoid grainstones of the Choteč Formation. A plausible crinoid and/or calcimicrobe origin for these peloids is suggested here. The second group is represented by two morphotypes of calcispheres, exhibiting different stages of grain obliteration (Fig. 8).

\section{Depositional environments for peloid formation}

The peloids which we discuss in this paper are of skeletal origin (calcispheres, crinoid and/or calcimicrobial origin). The processes of peloid formation mentioned above, related to grain alteration, cannot be ruled out and most probably there was an interplay of several processes. The calcimicrobial (Girvanella) peloids are most probably the result of mechanical and biological abrasion of Girvanella clusters or crusts.
For an appraisal of the most likely process which led to the formation of the other types of peloids mentioned, the depositional environment must be considered. The peloids recorded in the grainstones of the Choteč Formation were transported from more shallow water settings downwards by calciturbidites (Fig. 2F). Their shallow-water origin was already suggested by Chlupáč (1959). Calcispheres, isolated Girvanella filaments, and calcisphere-derived peloids also occur in the autochthonous, micritic sediments of the Choteč and Třebotov limestones (Fig. 2C, D). However, they occur only rarely. This suggests that the original life habitat of calcispheres was a shallow-water, nearshore environment. This conclusion is consistent with most of the studies of Paleozoic calcisphere occurrences (see references above). Other constituents of the grainstones are crinoidal ossicles, rare Girvanella clusters, and peloids derived from them. The environment was probably sheltered, for example by a crinoidal meadow bar, and calm. It is important to mention that neither calcispheres, nor peloids, were recorded from the shallow-water Suchomasty Limestone which is comprised of crinoidal wackestones and packstones. This is a shallow-water equivalent of the Třebotov Limestone. This leads to two questions: why are calcispheres present, although not abundantly in the offshore Třebotov Limestone but do not occur in its shallowwater counterpart - the Suchomasty Limestone (Fig. 2E)? The second question is why calcisphere blooms and intense grain diminution resulting in peloid formation took place during the sedimentation of the Choteč Formation? Before 


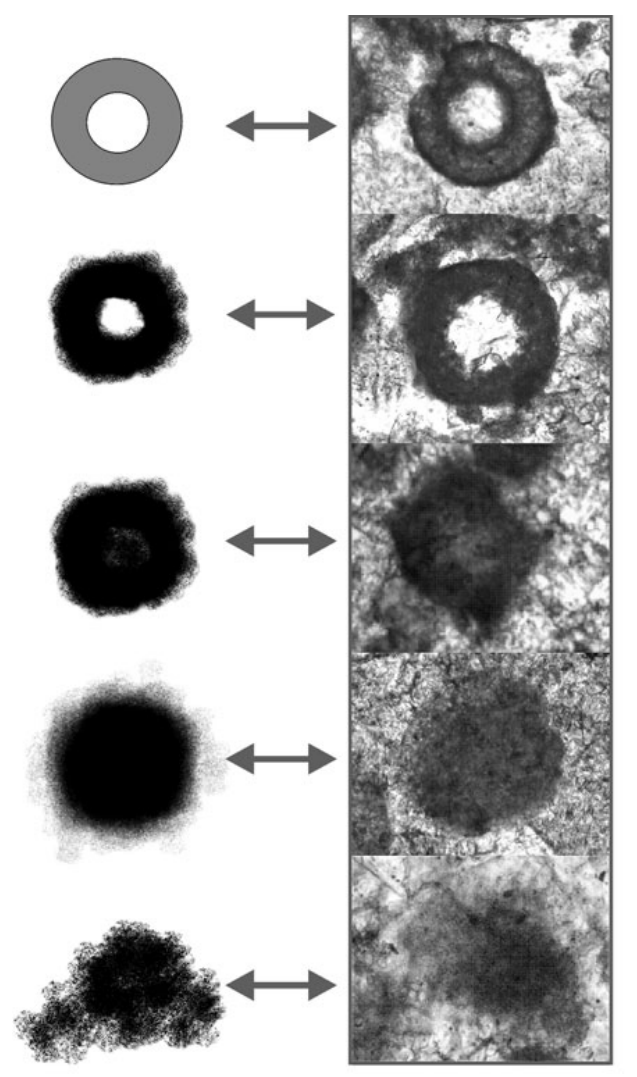

Calcisphere with dark micritic coating and well constrained grain boundaries.

Micritization in progress, more diffuse and thicker grain boundaries, but still well recognizable as a calcisphere.

\begin{abstract}
Advanced grain infestation. Originally hollow centre of calcisphere still distinguishable.
\end{abstract}

Rounded peloid - probably completely micritized calcisphere.

Subsequent break-up of weakened grain (peloid).

Figure 8. Schematic sketch showing gradual changes taking place during micritization of calcispheres and subsequent peloid break up.

these questions can be answered it is necessary to mention that the Devonian deposits of the Prague Basin represent only erosional relicts, with the original extend being much wider (e.g. Chlupáč et al. 1998). It is therefore possible that coeval facies of the Suchomasty Limestone with calcispheres are not preserved (or not exposed). This would explain the presence of calcispheres in the Třebotov Limestone and their absence in the shallow-water Suchomasty Limestone. Another feature to be considered is not only the lack of micritized calcispheres, but also other peloids in the Suchomasty Limestone. Considering the plausible peloid formation processes as depicted above (Figs 7, 8), one of the mechanisms listed could shed more light on this problem, namely the micritization caused by biochemical and/or physical activity of various organisms. When taking this process into account, it seems that the lack of peloids in the sediments deposited prior to the deposition of the Choteč Formation can be explained by the lack of such organisms. Identification of the organisms causing micritization is not possible in our case, we could only speculate about their nature. It can be assumed, however, that the micritization processes took place in shallow water. This assumption, together with findings of Girvanella, points to a photoautotrophic mode of life for the micritization-causing organisms. Nevertheless, this is only speculation as not all organisms causing micritization are necessarily photoautotrophic. In addition, the light requirements of Girvanella species are also not a straightforward issue (Khoja \& Whitton 1971, Riding 1975, White \& Shilo 1975).

The question as to what biological activity led to grain diminution cannot be satisfactorily answered. Micritization sensu Bathurst (1966) is plausible, yet cannot be proved as no bores could be observed in the micritized grains as the peloids were observed only in thin sections which are too thick for such observations. It should be kept in mind, however, that the processes depicted by Bathurst (1966, 1975) are ubiquitous in modern marine environments (e.g. Alexandersson 1972, Bathurst 1975, Hladil et al. 2004). Another process which could also lead to peloid formation, namely microbial degradation, should also be taken into consideration. As mentioned above, the presence of a mucilaginous envelope around calcisphere bodies is suggested here. The microbial degradation (and probably subsequent physical erosion) of the mucilage could have resulted in the features already described, i.e. a micritic rim in different states of preservation. Generally speaking, the mucilage secreted by organisms or individual cells is a valuable source of proteins and saccharide (Decho \& Herndl 1995 and references herein), therefore microbial activity on this material would not be surprising. Considering the restriction of peloid occurrences to a specific time interval (corresponding to the uppermost partitus and 
costatus zones) and a specific environment (shallow water), the interplay of micritization sensu Bathurst (1966), microbial activities, and subsequent physical erosion seems to be a plausible scenario for peloid formation. This situation may prompt another question, why were micritization-causing organisms so prolific during the sedimentation of the Choteč Formation? A detailed reasoning is beyond the scope of this paper. However, as implied from research linked to the first author's Ph.D., indirect evidence for a higher nutrient load during sedimentation of the Choteč Formation exists, e.g., accumulations of large (up to $500 \mu \mathrm{m}$ ), thick-walled phycomata of prasinophycean algae. Therefore, the specific environmental conditions linked to the Basal Choteč event (Chlupáč \& Kukal 1986, 1988), e.g., higher nutrient load, were probably established, which eventually led to higher populations of prasinophytes, calcispheres and microendolithic organisms.

\section{Formation of carbonate mud}

Different stages of preservation were observed in the samples, from comparatively well-preserved components to peloids with almost obscured grain boundaries caused by micritization. The processes related to micritization weakened the clasts (peloids), leaving them more susceptible to the mechanical effects of water turbulence, biological activity on the sea bottom ("biological mill") and transport, which subsequently led to physical abrasion and breakdown of peloids into $\mu \mathrm{m}$-sized calcium carbonate crystals - the lime mud.

Therefore we assume that the diminution of skeletal grains (especially calcispheres and crinoid ossicles) via micritization and/or microbial degradation probably finally resulted in the accumulation of large quantities of lime mud.

\section{Summary and conclusions}

1. Micritized calcispheres and several types of peloids were recorded in particular from the calciturbiditic beds of the Choteč Formation. The first group of peloids is represented by small, rounded peloids of the size $80-180 \mu \mathrm{m}$. Based on the similar shape and size and the joint occurrence with partially micritized calcispheres, it is concluded that these peloids represent totally micritized calcispheres. The second type is represented by peloids with more distinct grain boundaries and a rounded polygonal shape, for which a crinoid and/or calcimicrobial origin is suggested. The third peloid type recorded is of Girvanella cluster origin, as the filaments of this cyanobacterium are still recognizable within the peloids.

2. Possible mechanisms for peloid formation have been suggested, namely micritization sensu Bathurst (1966) and/or a microbial degradation and subsequent physical and/or biological erosion of weakened clasts.

3. The micritic rim, which was observed in all of the calcispheres studied, is regarded here as being related to the original nature of the calcispheres, and hence the presence of a mucilaginous envelope surrounding the calcisphere bodies was suggested. Taking into consideration the plausible presence of mucilage, the calcisphere size and their mass accumulations, this suggests a planktic mode of life.

4. The formation of peloids and mass occurrences of calcispheres are specific features of the Choteč Formation. It is concluded, that these are the results of the onset of specific environmental conditions during sedimentation of this unit (Basal Choteč event), i.e. higher nutrient load. Higher amount of available nutrients could have led to an increase in populations of calcispheres and microendolithic organisms causing micritization and subsequent formation of peloids, the diminution of which could have resulted in the accumulation of larger quantities of lime mud.

5. A noticeable increase in calcisphere abundance was recorded from the Eifelian onwards (early partitus Zone, Middle Devonian). No significant faunistic (except for some innovations among trilobites) or lithological changes are known from the Lower-Middle Devonian boundary interval in the Prague Basin (Chlupáč 1985, Chlupáč et al. 2000). There is a growing body of evidence, however, that environmental changes, which culminated during sedimentation of the Choteč Limestone (costatus Zone), took place earlier, close to the Lower-Middle Devonian boundary (base of partitus Zone).

5. Even though the quantities of calcisphere/peloid-derived lime mud are difficult to estimate, the contribution of micritized grains and peloids to the production of lime mud is undoubted. Moreover, if the mode of life of calcispheres suggested here is correct, then the contribution of calcareous plankton to lime mud accumulation took place much earlier then previously thought, as already suggested by Munnecke \& Servais (2008) and Munnecke et al. (1999).

\section{Acknowledgements}

This work was supported by grants from the Grant Agency of the Academy of Science (KJB 307020602), the Czech-American Cooperation Program (Kontakt ME08011) and grants from the Czech Geological Survey $(3325,3333,323000)$. The first author also acknowledges the Palaeontological Association for the Sepkoski Grant award, which also allowed the study to proceed. We thank the reviewers Lubomir F. Jansa (Dalhousie University, 
Canada) and Michaela Bernecker (German University of Technology, Oman), and the handling editor, Jindřich Hladil (Institute of Geology AS CR, v.v.i., Czech Republic) for their most constructive comments, which greatly improved the manuscript. Pawel Filipiak (University of Silesia, Poland) and Thomas Servais (Lille University of Science and Technology, France) are also gratefully acknowledged for their advice on some problematic specimens.

\section{References}

Adams, T.D., Khalili, M. \& SAID, A.K. 1967. Stratigraphic significance of some oligosteginid assemblages from Lurestan Province, northwest Iran. Micropaleontology 13(1), 55-67. DOI $10.2307 / 1484805$

ALEXANDERSSON, E.T. 1972. Micritization of carbonate particles: process of precipitation and dissolution in modern shallow-marine sediments. Universitet Uppsala, Geologiska Institut Bulletin 7, 201-236.

Antoshrina, A.I. 2006. Palaeoenvironmental implications of Palaeomicrocodium in Upper Devonian microbial mounds of the Chernyshev Swell, Timan-northern Ural Region. Facies 52, 611-625. DOI 10.1007/s10347-006-0083-z

Bathurst, R.G.C. 1966. Boring algae, micrite envelopes and lithification of molluscan biosparites. Geological Journal 5, 15-32. DOI 10.1002/gj.3350050104

Bathurst, R.G.C. 1970. Problems of lithification in carbonate muds. Geologist's Association Proceedings 81, 429-440. DOI 10.1016/S0016-7878(70)80005-0

Bathurst, R.G.C. 1975. Carbonate sediments and their diagenesis. 620 pp. Developments in Sedimentology 12, Elsevier, Amsterdam.

Bein, A. \& Reiss, Z. 1976. Cretaceous Pithonella from Israel. Micropaleontology 22(1), 83-91. DOI 10.2307/1485322

Bellanca, A., Distefano, P. \& Neri, R. 1995. Sedimentology and isotope geochemistry of Carnian deep-water marl/limestone deposits from the Sicani Mountains, Sicily: environmental implications and evidence for a planctonic source of lime mud. Palaeogeography, Palaeoclimatology, Palaeoecology 114, 111-129. DOI 10.1016/0031-0182(95)00077-Y

Berkyová, S. 2009. Lower-Middle Devonian (upper EmsianEifelian, serotinus-kockelianus zones) conodont faunas from the Prague Basin, the Czech Republic. Bulletin of Geociences 84(4), 667-686. DOI 10.3140/bull.geosci.1153

Bishop, B.A. 1972. Petrography and origin of Cretaceous limestones, Sierra de Picachos vicinity, Buevo Leon, Mexico. Journal of Sedimentary Petrology 42(2), 270-286.

Bosak, A., SouZA-Egipsy, V. \& Newman, D.K. 2004. A laboratory model of abiotic peloid formation. Geobiology 2, 189-198. DOI 10.1111/j.1472-4677.2004.00031.x

Bown, P.R., LeEs, J.A. \& Young, J.R. 2004. Calcareous nannoplankton evolution and diversity, 481-508. In THIERSTEIN, H. \& Young, J.R. (eds) Coccolithophores - From Molecular Processes to Global Impact. Springer, Berlin.

BucZynski, C. \& ChafeTz, H.S. 1993. Habit of bacterially induced precipitates of calcium carbonate: examples from laboratory experiments and recent sediments, 105-116. In REZAK, R. \& Lavoie, D.L. (eds) Carbonate microfabrics. Frontiers in
Sedimentary Geology. Springer-Verlag, Berlin, New York, Heidelberg.

BudIL, P. 1995. Demonstrations of the Kačák event (Middle Devonian, uppermost Eifelian) at some Barrandian localities. Bulletin of the Czech Geological Survey 70(4), 1-24.

Butterfield, N.J. \& RAInBiRD, R.H. 1998. Diverse organicwalled fossils, including "possible dinoflagellates" from the Early Neoproterozoic of arctic Canada. Geology 26, 963-966. DOI 10.1130/0091-7613(1998)026<0963:DOWFIP>2.3.CO;2

ChAfETZ, H.S. 1986. Marine peloids: a product of bacterially induced precipitation of calcite. Journal of Sedimentary Petrology 56(6), 812-817.

ChluPÁČ, I. 1959. Faciální vývoj a biostratigrafie břidlic dalejských a vápenců hlubočepských (eifel) ve středočeském devonu. Sborník Ústředního ústavu geologického 25, 445-511.

Chlupéč, I. 1977. The phacopid trilobites of the Silurian and Devonian of Czechoslovakia. Rozpravy Ústředního ústavu geologického 43, 1-172.

Chlupéč, I. 1983. Trilobite assemblages in the Devonian of the Barrandian area and their relations to paleoenvironments. Geologica et Palaeontologica 17, 45-73.

Chlupáč, I. 1985. Comments on the Lower-Middle Devonian boundary. Courier Forschungsinstitut Senckenberg 75, 389-400.

Chlupáč, I. \& Kukal, Z. 1986. Reflection of possible global Devonian events in the Barrandian area, C.S.S.R., 169-179. In Walliser, O. (ed.) Lecture Note in Earth Sciences, Global Bio-events. Springer Verlag, Berlin.

Chlupéč, I. \& Kukal, Z. 1988. Possible global events and the stratigraphy of the Palaeozoic of the Barrandian (CambrianMiddle Devonian, Czechoslovakia). Sborník geologických věd, Geologie 43, 83-146.

ChlupÁČ, I., LuKEŠ, P. \& ZikmundovÁ, J. 1979. The Lower/Middle Devonian boundary beds in the Barrandian area, Czechoslovakia. Geologica et Palaeontologica 13, 125-156.

Chlupáč, I., Havlíček, V., KŘíž, J., Kukal, Z. \& Štorch, P. 1998. Palaeozoic of the Barrandian (Cambrian to Devonian). 183 pp. Czech Geological Survey, Prague.

Chlupéč, I., Feist, R. \& Morzadec, P. 2000. Trilobites and standard Devonian stage boundaries. Courier Forschungsinstitut Senckenberg 220, 87-98.

Cloud, P.E. 1962. Environment of calcium carbonate deposition west of Andros Islands, Bahamas. United States Geological Survey Professional Paper 350, 1-138.

Coniglio, M. \& James, N.P. 1985. Calcified algae as sediment contributors to early Paleozoic limestones: evidence from deep-water sediments of the Cow Head Group, western Newfoundland. Journal of Sedimentary Petrology 55(5), 746-754.

Decho, A.W. \& HerndL, G.J. 1995. Microbial activities and the transformation of organic matter within mucilaginous material. The Science of the Total Environment 165, 33-42. DOI 10.1016/0048-9697(95)04541-8

Di Nocera, S. \& Scandone, P. 1977. Triassic nannoplankton limestones of deep basin origin in the central Mediterrannnean region. Palaeogeography, Palaeoclimatology, Palaeoecology 21, 101-111. DOI 10.1016/0031-0182(77)90008-6

DitTrich, M. \& OвST, M. 2004. Are picoplankton responsible for calcite precipitation in lakes? Ambio 33(8), 559-564.

Dunham, R.J. 1962. Classification of carbonate rocks according to depositional structure, 108-112. In HAM, W.E. (ed.) Classi- 
fication of carbonate rocks. Memoirs of American Association of Petroleum Geologists 1.

Elrick, M., Berkyová, S., Klapper, G., Sharp, Z., Joachimski, M. \& FRÝDA, J. 2009. Stratigraphic and oxygen isotope evidence for My-scale glaciation driving eustasy in the EarlyMiddle Devonian greenhouse world. Palaeogeography, Palaeoclimatology, Palaeoecology 276, 170-181. DOI 10.1016/j.palaeo.2009.03.008

FÅhreaus, L.E., Slatt, R.M. \& Nowlan, G.S. 1974. Origin of carbonate pseudopellets. Journal of Sedimentary Petrology 44(1), 27-29.

FLÜGEL, E. 2004. Microfacies of carbonate rocks, Analysis, Interpretation and Application. 976 pp. Springer-Verlag, Berlin \& Heidelberg.

FoLK, R.L. 1974. The natural history of crystalline calcium carbonate: effect of magnesium content and salinity. Journal of Sedimentary Petrology 44(1), 40-53.

Franke, W. 1989. Variscan plate tectonics in Central Europe-current ideas and open questions. Tectonophysics 169, 221-228. DOI 10.1016/0040-1951(89)90088-7

FranKe, W. 2000. The mid-European segment of the Variscides: tectonostratigraphic units, terrane boundaries and plate tectonic evolution, 337-354. In Franke, W., HAAK, V., OnCKen, O. \& TANNER, D. (eds) Orogenic Processes: Quantification and Modelling in the Variscan Belt. Geological Society of London, Special Publications 179.

Friedman, G.M., Gebelein, C.D. \& SAnders, J.E. 1971. Micritic envelopes of carbonate grains are not exclusively of photosynthetic algal origin. Sedimentology 16, 89-96. DOI 10.1111/j.1365-3091.1971.tb00220.x

Gartner, S. 1977. Nannofossils and biostratigraphy: an overview. Earth-Science Reviews 13, 227-250. DOI 10.1016/0012-8252(77)90001-0

GunatilaKA, A. 1976. Thallophyte boring and micritization within skeletal sands from Connemara, western Ireland. Journal of Sedimentary Petrology 46(3), 548-554.

HAVLíčEK, V. 1981. Development of a linear sedimentary depression exemplified by the Prague Basin (Ordovician-Middle Devonian; Barrandian area-central Bohemia). Sborník geologických věd, Geologie 35, 7-48.

Havlí̌̌EK, V. \& KuKal, Z. 1990. Sedimentology, benthic communities, and brachiopods in the Suchomasty (Dalejan) and Acanthopyge (Eifelian) Limestones of the Koněprusy area (Czechoslovakia). Sborník geologických věd, Paleontologie 31, 105-205.

HLadil, J. 2004. Environmental relationships of endolithic microborers and substrates in Barrandian limestones of Devonian age, Czech Republic, p. 26. In Mikuláš, R. (ed.) $4^{\text {th }}$ International Bioerosion Workshop, IBW-4, Abstract Book, Prague.

Hladil, J., Čejchan, P., Gabašová, A., Táborský, Z. \& HlaDíKOVÁ, J. 1996. Sedimentology and orientation of tentaculite shells in turbidite lime mudstone to packstone: Lower Devonian, Barrandian, Bohemia. Journal of Sedimentary Research B 66, 888-899.

Hladil, J., Carew, J.L., Mylroie, J.E., Pruner, P., Kohout, T., Jell, J.S., Lacka, B. \& LangrovÁ, A. 2004. Anomalous magnetic susceptibility values and traces of subsurface microbial activity in carbonate banks on San Salvador Island, Bahamas. Facies 50, 161-182. DOI 10.1007/s10347-004-0013-x
House, M.R. 2002. Strength, timing, setting and cause of midPalaeozoic extinctions. Palaeography, Palaeoclimatology, Palaeoecology 181, 5-25.

DOI 10.1016/S0031-0182(01)00471-0

Hutchings, P. 2008. Role of polychaetes in bioerosion of coral substrates, 249-264. In WisshaK, M. \& TAPANILA, L. (eds) Current Developments in Bioerosion. Erlangen Earth Conference Series, Springer, Berlin.

KаснLí, V. 1999. Relationship between Moldanubicum, the Kutná Hora crystalline unit, and Bohemicum (Central Bohemia, Czech Republic): a result of the polyphase nappe tectonics. Journal of the Czech Geological Society 44, 201-289.

KAźMIERCZAK, J. 1975. Colonial Volvocales (Chlorophyta) from the Upper Devonian of Poland and their paleoenvironmental significance. Acta Palaeontologica Polonica 20(3), 73-89.

KAŹMIERCZAK, J. 1976. Volvocacean nature of some Palaeozoic non-radiosphaerid calcispheres and parathuramminid "foraminifera". Acta Palaeontologica Polonica 21(3), 245-262.

KażmiercZak, J., Coleman, M.L., Gruszczyński, M. \& Kempe, S. 1996. Cyanobacterial key to the genesis of micritic and peloidal limestones in ancient seas. Acta Palaeontologica Polonica 41(4), 319-338.

KaźmiercZak, J. \& Kremer, B. 2005. Post-mortem calcified Devonian acritarchs as a source of calcispheric structures. Facies 51, 554-565. DOI 10.1007/s10347-005-0071-8

Kendall, C.G.S.C. \& Skipwith, P.A. D’E. 1969. Holocene shallow-water carbonate and evaporite sediments of Khor al Bazam, Abu Dhabi, Southwest Persian Gulf. The American Asscociation of Petroleum Geologists Bulletin 53(4), 841-869.

KeupP, H. 1981. Die kalkigen Dinoflagellaten-Zysten der borealen Unter-Kreide (Unter-Hauterivium bis Unter-Albium). Facies 5, 1-190. DOI 10.1007/BF02536655

Кнола, T. \& Whiтton, B.A. 1971. Heterotrophic growth of bluegreen algae. Archives of Microbiology 79(3), 280-282. DOI 10.1007/BF00408790

Klement, K.W. \& Toomey, D.F. 1967. Role of the blue-green alga Girvanella in skeletal grain destruction and lime-mud formation in the Lower Ordovician of west Texas. Journal of Sedimentary Petrology 37(4), 1045-1051.

Kobluk, D.R. \& Risk, M.J. 1977. Micritization and carbonate-grain binding by endolithic algae. American Association of Petroleum Geologists Bulletin 61, 1069-1082.

Konishi, K. 1958. Devonian calcareous algae from Alberta, Canada, 85-109. In Johnson, J.H. \& Konishi, K. (eds) Studies of Devonian algae. Quarterly of the Colorado School Mines 53(2).

KuKAL, Z. \& JÄGER, O. 1988. Siliciclastic signal of the Variscan orogenesis: the Devonian Srbsko Formation of Central Bohemia. Věstník Ústředního ústavu geologického 63, 65-80.

LASEMI, Z. \& SANDBERG, P.A. 1984. Transformation of aragonite-dominated lime muds to microcrystalline limestones. $\mathrm{Ge}$ ology 12, 420-423.

DOI 10.1130/0091-7613(1984)12<420:TOALMT>2.0.CO;2

LowENSTAM, H.A. 1955. Aragonite needles secreted by algae and some sedimentary implications. Journal of Sedimentary Petrology 25(4), 270-272.

Lowenstam, H.A. \& Epstein, S. 1957. On the origin of sedimentary aragonite needles of the Great Bahama Bank. The Journal of Geology 65(4), 364-375. DOI 10.1086/626439 
MacintYre, I.G. 1985. Submarine cements - the peloidal question. SEPM Special Publication 36, 109-116.

Macintyre, I.G., Prufert-Bebout, L. \& Reid, R.P. 2000. The role of endolithic cyanobacteria in the formation of lithified laminae in Bahamian stromatolites. Sedimentology 47, 915-921. DOI 10.1046/j.1365-3091.2000.00327.x

MARSZALEK, D.S. 1975. Calcisphere ultrastructure and skeletal aragonite from the alga Acetabularia antillana. Journal of Sedimentary Petrology 45(1), 266-271.

Matthews, R.K. 1966. Genesis of recent lime mud in southern British Honduras. Journal of Sedimentary Petrology 36(2), 428-454.

McCallum, M.F. \& GuhathakuRta, K. 1970. The precipitation of calcium carbonate from sea water by bacteria isolated from Bahama Bank sediments. Journal of Applied Bacteriology 33, 649-655.

Melim, L.A, Westrhal, H., Swart, P.K., Eberli, G.P. \& MunNECKE, A. 2002. Questioning carbonate diagenetic paradigms: evidence from the Neogene of the Bahamas. Marine Geology 185, 27-53. DOI 10.1016/S0025-3227(01)00289-4

Milliman, J.D., Freile, D., Steinen, R.P. \& Wilber, R.J. 1993. Great Bahama Bank aragonitic muds: mostly inorganically precipitated, mostly exported. Journal of Sedimentary Petrology 63(4), 589-595.

Moldowan, J.M., Dahl, J., Jacobson, S.R., Huizinga, B.J., Fago, F.J, Shetty, R., Watt, D.S. \& Peters, K.E. 1996. Chemostratigraphic reconstruction of biofacies: molecular evidence linking cyst-forming dinoflagellates with pre-Triassic ancestors. Geology 24(2), 159-162. DOI 10.1130/0091-7613(1996)024<0159:CROBME>2.3.CO;2

MonTY, C.L.V. 1995. The rise and nature of carbonate mudmounds: An introductory actualistic approach, 11-48. In Monty, C.L.V., Bosence, D.W.J., Bridges, P.H. \& Pratt, B.R. (eds) Carbonate Mud-Mounds. Their Origin and Evolution. Special Publication of the International Association of Sedimentologists 23.

Morse, J.W., Gledhill, D.K. \& Millero, F.J. 2003. $\mathrm{CaCO}_{3}$ precipitation kinetics in waters from the Great Bahama Bank: implications for the relationship between hydrochemistry and whitings. Geochimica et Cosmochimica Acta 67(15), 2819-2826. DOI 10.1016/S0016-7037(03)00103-0

MoshiER, S.O. 1989. Microporosity in micritic limestones: a review. Sedimentary Geology 63, 191-213. DOI 10.1016/0037-0738(89)90132-2

Munnecke, A. \& SAmtleben, C. 1996. The formation of micritic limestones and the development of limestone-marl alternations in the Silurian of Gotland, Sweden. Facies 34, 159-176. DOI 10.1007/BF02546162

Munnecke, A., Samtleben, C., Servais, T. \& Vachard, D. 1999. SEM-observation of calcareous micro- and nannofossils incertae sedis from the Silurian of Gotland, Sweden: preliminary results. Geobios 32(2), 307-314.

DOI 10.1016/S0016-6995(99)80044-8

Munnecke, A. \& Servais, T. 2008. Palaeozoic calcareous plankton: evidence from the Silurian of Gotland. Lethaia 41, 185-194. DOI 10.1111/j.1502-3931.2008.00113.x

Munnecke, A., Westphal, H. \& Kölbl-Ebert, M. 2008. Diagenesis of plattenkalk: examples from the Solnhofen area (Upper Jurassic, S-Germany). Sedimentology 55(6), 1931-1946. DOI 10.1111/j.1365-3091.2008.00975.x
Munnecke, A., Westphal, H., Reijmer, J.J.G. \& Samtleben, C. 1997. Microspar development during early marine burial diagenesis: a comparison of Pliocene carbonates from the Bahamas with Silurian limestones from Gotland (Sweden). Sedimentology 44(6), 977-990.

DOI 10.1111/j.1365-3091.1997.tb02173.x

Mutterlose, J., Bornemann, A. \& Herrle, J.O. 2005. Mesozoic calcareous nannofossils - state of the art. Paläontologische Zeitschrift 79(1), 113-133.

NeugebauER, J. 1978. Micritization of crinoids by diagenetic solution. Sedimentology 25, 267-283.

DOI 10.1111/j.1365-3091.1978.tb00312.x

Neumann, A.C. \& Land, L.S. 1975. Lime mud deposition and calcareous algae in the Bight of Abaco, Bahamas: a budget. Journal of Sedimentary Petrology 45(4), 763-786.

Nicoll, R.S \& Foster, C.B. 1994. Late Triassic conodont and palynomorph biostratigraphy and conodont thermal maturation, North West shelf Australia. Journal of Australian Geology and Geophysics 15(1), 101-118.

Perkins, R.D. \& Halsey, S.D. 1971. Geologic significance of microboring fungi and algae in Carolina Shelf sediments. Journal of Sedimentary Petrology 41(3), 843-853.

Peterhänsel, A. \& Pratt, B.R. 2001. Nutrient-triggered bioerosion on a giant carbonate platform masking the postextinction Famennian benthic community. Geology 29, 1079-1082.

DOI 10.1130/0091-7613(2001)029<1079:NTBOAG >2.0.CO;2

PetráneK, J. 1946. Hranice hlubočepských vápenců a srbských břidlic v Hlubočepích u Prahy. Sborník Státního geologického ústavu 13, 259-278.

Petránek, J. 1950. Petrografická studie o nejmladších devonských vrstvách v Dalejském údolí u Prahy. Rozpravy České akademie věd a umění, Třida II 60, 1-16.

Plusquelec, Y. \& Hladil, J. 2001. Tabulate corals of Ibarmaghian affinities in the Upper Emsian of Bohemia. Geologica et Palaeontologica 35, 31-51.

PratT, B. 2001. Calcification of cyanobacterial filaments; Girvanella and the origin of lower Paleozoic lime mud. Geology 29(9), 763-766.

DOI 10.1130/0091-7613(2001)029<0763:COCFGA >2.0.CO;2

PURDY, E.G. 1968. Carbonate diagenesis: an environmental survey. Geologica Romana 7, 183-228.

REID, R.P. 1987. Nonskeletal peloidal precipitates in Upper Triassic reefs, Yukon Territory (Canada). Journal of Sedimentary Petrology 57(5), 893-900.

ReID, R.P. \& MACINTYRE, I.G. 1998. Carbonate recrystallization in shallow marine environments: a widespread diagenetic process forming micritized grains. Journal of Sedimentary Research 68(5), 928-946.

Reid, R.P. \& Macintyre, I.G. 2000. Microboring versus recrystallization: further insight into the micritization process. Journal of Sedimentary Research 70, 24-28.

DOI 10.1306/2DC408FA-0E47-11D7-8643000102C1865D

Reid, R.P., Macintyre, I.G. \& Post, J.E. 1992. Micritized skeletal grains in northern Belize lagoon: a major source of Mg-calcite mud. Journal of Sedimentary Petrology 62(1), 145-156.

ReitLinger, E.A. 1957. Spheres in the Devonian deposits of the Russian Platform. Doklady Akademii Nauk SSSR 115(4), 774-776.

ReITNER, J. 1993. Modern cryptic microbialite/metazoan facies 
from Lizard Island (Great Barrier Reef, Australia), formation and concepts. Facies 29, 3-40. DOI 10.1007/BF02536915

REYNOLDS, C.S. 2006. The ecology of phytoplankton. 552 pp. Cambridge University Press, Cambridge. DOI 10.1017/CBO9780511542145

Rich, M. 1965. "Calcispheres" from the Duperow Formation (Upper Devonian) in western North Dakota. Journal of Paleontology 39(1), 143-145.

Ridgwell, A. 2005. A Mid Mesozoic Revolution in the regulation of ocean chemistry. Marine Geology 217, 339-357. DOI 10.1016/j.margeo.2004.10.036

RIDING, R. 1975. Girvanella and other algae as depth indicators. Lethaia 8, 173-197.

DOI 10.1111/j.1502-3931.1975.tb01310.x

RIDING, R. 2000. Microbial carbonates: the geological record of calcified bacterial-algal mats and biofilms. Sedimentology 47(1), 179-214. DOI 10.1046/j.1365-3091.2000.00003.x

Robbins, L.L. \& Blackwelder, P.L. 1992. Biochemical and ultrastructural evidence for the origin of whitings: A biologically induced calcium carbonate precipitation mechanism. Geology 20, 464-468.

DOI 10.1130/0091-7613(1992)020<0464:BAUEFT>2.3.CO;2

RupP, A.W. 1966. Origin, structure, and environmental significance of Recent and fossil calcispheres. Geological Society of America, Abstracts with Programs 101, p. 186.

Samankassou, E., Tresch, J. \& Strasser, A. 2005. Origin of peloids in early Cretaceous deposits, Dorset, South England. Facies 51, 264-273. DOI 10.1007/s10347-005-0002-8

SANTOS, A. \& MAYORAL, E. 2006. Bioerosive structures of sclerozoan foraminifera from the lower Pliocene of southern Spain: a contribution to the palaeoecology of marine hard substrates communities. Palaeontology 49(4), 719-732. DOI 10.1111/j.1475-4983.2006.00560.x

Scholle, P.A. \& Ulmer-Scholle, D.S. 2003. A color guide to the petrography of carbonate rocks: grains, textures, porosity, diagenesis. The American Asscociation of Petroleum Geologists Memoir 77, 1-474.

ScofFIN, T.P. 1993. Microfabrics of carbonate muds in reefs, 65-74. In RezaK, R. \& LAvoIE, D.L. (eds) Carbonate microfabrics. Frontiers in Sedimentary Geology. Springer-Verlag, Berlin, New York, Heidelberg.

Serrano, H.B., Morse, J.W. \& Millero, F.J. 2009. The formation of whitings on the Little Bahama Bank. Marine Chemistry 113, 1-8. DOI 10.1016/j.marchem.2008.10.006

Servais, T., Munnecke, A. \& Versteegh, G.J.M. 2009. Silurian calcispheres (Calcitarcha) of Gotland (Sweden): comparisons with calcareous dinoflagellates. Comptes Rendus Palevol 8, 527-534. DOI 10.1016/j.crpv.2009.04.002

Shinn, E.A., Steinen, R.P., Lidz, B.H. \& Swart, P.K. 1989. Whitings, a sedimentological dilemma. Journal of Sedimentary Petrology 59(1), 147-161.

Sorby, H.C. 1879. Anniversary address of the president (The structure and origin of limestones). Proceedings of the Geological Society of London 35, 56-95.

StANTON, R.J. JR. 1967. Radiosphaerid calcispheres in North America and remarks on calcisphere classification. Micropaleontology 13(4), 465-472. DOI 10.2307/1484721

STEINEN, R. 1982. SEM observations on the replacement of Bahaman aragonitic mud by calcite. Geology 10(9), 471-475. DOI 10.1130/0091-7613(1982)10<471:SOOTRO > 2.0.CO;2
StIEGLitZ, R.D. 1972. Scanning electron microscopy of the fine fraction of recent carbonate sediments from Bimini, Bahamas. Journal of Sedimentary Petrology 42(1), 211-226.

Stockman, K.W., Ginsburg, R.N. \& Shinn, E.A. 1967. The production of lime mud by algae in south Florida. Journal of Sedimentary Petrology 37(2), 633-648.

SuchÝ, V. 1991. Karbonátové tempestity v barrandienském středním devonu. Horniny ve vědách o zemi, 77-105. Sborník k 60. výroči ústavu a katedry petrologie př́rodovědecké fakulty Univerzity Karlovy. Karolinum, Praha.

SwinchatT, J.P. 1965. Significance of constituent composition, texture, and skeletal breakdown in some recent carbonate sediments. Journal of Sedimentary Petrology 35(1), 71-90.

Tudhope, A.W. \& Risk, M.J. 1985. Rate of dissolution of carbonate sediments by microboring organisms, Davies Reef, Australia. Journal of Sedimentary Petrology 55(3), 440-447.

Vecsei, A. \& Duringer, P. 1998. Problematic calcispheres from the Upper Muschelkalk (Middle Triassic) of eastern France as producers of calcisiltite and micrite in shallow-water limestones. Paläontologische Zeitschrift 72(1/2), 31-39.

Versteegh, G.J.M., Servais, T., Munnecke, A., Streng, M. \& VACHARD, D. 2009. A discussion and proposal concerning the use of the term calcispheres. Palaeontology 52(2), 343-348. DOI 10.1111/j.1475-4983.2009.00854.x

VON RAumer, J.F. \& StAmpfli, G.M. 2008. The birth of the Rheic Ocean-Early Palaeozoic subsidence patterns and subsequent tectonic plate scenarios. Tectonophysics 461(1-4), 9-20. DOI 10.1016/j.tecto.2008.04.012

Walliser, O.H. 1985. Natural boundaries and Commission boundaries in the Devonian. Courier Forschungsinstitut Senckenberg 75, 401-408.

WaLLiseR, O.H. 1996. Global events in the Devonian and Carboniferous. In WALLISER, O.H. (ed.) Global events and event stratigraphy in the Phanerozoic. 313 pp. Springer-Verlag, Berlin, Heidelberg, New York, London, Paris, Tokyo, Hong Kong.

White, A.W. \& Shilo, M. 1975. Heterotrophic growth of the filamentous blue-green alga Plectonema boryanum. Archives of Microbiology 102(1), 123-127. DOI 10.1007/BF00428356

Wiese, F., Wood, C.J. \& Kaplan, U. 2004. 20 years of event stratigraphy in NW Germany; advances and open questions. Acta Geologica Polonica 54(4), 639-656.

WilBer, R.J. \& NEUMANN, A.C. 1993. Effects of submarine cementation on microfabrics and physical properties of carbonate slope deposits, Northern Bahamas, 105-116. In REZAK, R. \& LAvoIE, D.L. (eds) Carbonate microfabrics. Frontiers in Sedimentary Geology. Springer-Verlag, Berlin, New York, Heidelberg.

Williamson, W.C. 1880. On the organization of the fossil plants of the coal-measures. Part X-including an examination of the supposed radiolarians of the Carboniferous rocks. Philosophical Transactions of the Royal Society of London 171, 493-539. DOI 10.1098/rstl.1880.0014

WinLAND, H.D. 1968. The role of high Mg calcite in the preservation of micrite envelopes and textural features of aragonite sediments. Journal of Sedimentary Petrology 38(4), 1320-1325.

WoLF, K.H. 1965. "Grain-diminution" of algal colonies to micrite. Journal of Sedimentary Petrology 35, 420-427.

YounG, H.R. \& Nelson, C.S. 1988. Endolitihic biodegradation of cool-water skeletal carbonates on Scott shelf, northwestern Vancouver Island, Canada. Sedimentary Geology 60, 251-267. DOI 10.1016/0037-0738(88)90123-6 